\title{
Variation of age and total length in Sotalia guianensis (Van Bénéden, 1864) (Cetacea, Delphinidae), on the coast of Espírito Santo state, Brazil
}

\author{
J. Y. Lima ${ }^{a *}$, A. P. M. Carvalho ${ }^{a}$, C. T. Azevedo ${ }^{a}$, L. A. Barbosa ${ }^{b}$ and L. S. Silveira ${ }^{a}$ \\ aLaboratório de Morfologia e Patologia Animal, Universidade Estadual do Norte Fluminense Darcy Ribeiro - UENF, \\ Av. Alberto Lamego, 2000, Parque Califórnia, CEP 28016-000, Campos dos Goytacazes, RJ, Brazil \\ 'Instituto ORCA, Rua São Paulo, 23, Praia da Costa, CEP 29101-315, Vila Velha, ES, Brazil \\ *e-mail: ju.ywasaki@gmail.com
}

Received: August 24, 2015 - Accepted: March 28, 2016 - Distributed: August 31, 2017

(With 4 figures)

\begin{abstract}
Variations of age and total length of Sotalia guianensis from the state of Espírito Santo, Brazil, were evaluated. Specimens were found stranded. Age and total length of 44 Guiana dolphins were assessed based on tooth analysis. Age varied between 0.5 year and 33 years (mean $=8.23$ years). Most specimens were between zero and 6 years old (47\%). Total length varied from $119 \mathrm{~cm}$ to $198 \mathrm{~cm}$, with mean of $172.52 \mathrm{~cm}$. Asymptotic length was reached at $185 \mathrm{~cm}$ and approximately 5-6 years of age. Mean total length and age were higher than in other regions of the distribution range of the species. Nevertheless, more studies have to be carried out to evaluate the morphological variations in S. guianensis populations in the study area and Brazil.
\end{abstract}

Keywords: Guiana dolphin, age, total length.

\section{Variação etária e de comprimento total de Sotalia guianensis (Van Bénéden, 1864) (Cetacea, Delphinidae), no Litoral do Espírito Santo, Brasil}

\section{Resumo}

Foram avaliadas variações de comprimento total e etárias de Sotalia guianensis provenientes do estado do Espírito Santo. Os espécimes foram encontrados encalhados. Idade e comprimento total de 44 S. guianensis foram avaliados com base na análise dentária. A idade variou entre 0,5 e 33 anos (média = 8,23 anos). A maioria dos exemplares tinha entre zero e seis anos de idade (47\%). O comprimento total variou de 119 a 198 centímetros, com média de 172,52 centímetros. O comprimento assintótico foi atingido com $185 \mathrm{~cm}$, aproximadamente entre 5-6 anos de idade. O comprimento total médio e a idade foram maiores que outras regiões de distribuição da espécie. No entanto, mais estudos devem ser realizados para avaliar as variações morfológicas em populações de $S$. guianensis na região e no Brasil.

Palavras-chave: golfinho das Guianas, idade, comprimento total.

\section{Introduction}

The Guiana dolphin (Sotalia guianensis, Van Bénéden, 1864 ) is found along the tropical and subtropical Atlantic coast of the South and Central Americas, from Honduras (Edwards and Schnell, 2001) to the state of Santa Catarina, Brazil (Simões-Lopes, 1988). Although it is one of the species that have been most studied in these regions, it is still considered insufficiently known by the International Union for Conservation of Nature (IUCN, 2003) and by the Brazilian environmental authorities (IBAMA, 2001).

Variations in growth pattern may be associated with seasonal changes, environmental factors, competition strategies, and patterns of reproduction investment (Amano and Miyazaki, 1992). Intraspecific morphological changes represent an important source of information in the identification of the variability of geographical and non-geographical elements. Currently, several types of data are used to identify populations. Studies about phenotypical characters (osteology, morphology, and pigmentation patterns) based on multivariate techniques have been consistently carried out to identify populations in several taxonomic groups (Wang et al., 1999).

Age estimates of cetaceans stand is a good tool to characterize populations and to understand the biology of individuals (Pinedo and Hohn, 2000; Butti et al., 2007; Azevedo et al., 2015; Carvalho et al., 2015). In this sense, 
the ability to estimate the age of small cetaceans is extremely important in natural history studies (Hohn et al., 1989).

The present study determined age and morphology variations in the Guiana dolphin in the state of Espírito Santo, Brazil.

\section{Material and Methods}

In total, 44 specimens of $S$. guianensis accidentally captured in fisheries or stranded in the state of Espírito Santo, Brazil, were used. Detailed information on specimens recovered and used in this study are provided in Table 1. Individuals were found between Conceição da Barra
(18 30’S), and Presidente Kennedy ( $\left.21^{\circ} 05^{\prime} \mathrm{S}\right)$, farther south. Initially, total length (TL) and sex of animals were established. Next, teeth were extracted to estimate age. The teeth whose roots were straight and that exhibited the lowest degree of wear of crown were chosen, independently of their position in the mandibles. The method described by Hohn et al. (1989) was adopted. At first, teeth were cut to $3-\mathrm{mm}$ to 5 -mm-thick sections parallel to the longest bucco-lingual axis using a low-speed metal saw equipped with diamond blades. Sides of sections were also removed to improve the action of the decalcification agent and facilitate the subsequent sectioning of tooth specimens using a microtome-cryostat. Tooth sections were soaked

Table 1. Sotalia guianensis data used in this study. Information includes specimen identification, collection date, sex (male: M, female: F, UN: unknown sex), total length (cm), locality, city, tissues samples stored and responsible staff. All tissues samples were stored at the ORCA institute's head office.

\begin{tabular}{|c|c|c|c|c|c|c|c|}
\hline Specimen & $\begin{array}{c}\text { Collection } \\
\text { date }\end{array}$ & Sex & $\begin{array}{l}\text { Total } \\
\text { length }\end{array}$ & Locality & City & Tissues samples stored & $\begin{array}{c}\text { Responsible } \\
\text { staff }\end{array}$ \\
\hline SOT.05 & $18 / 03 / 1996$ & $\mathrm{~F}$ & 189 & Itaparica & Vila Velha & Skeleton, teeth & L. Barbosa \\
\hline SOT.19 & $09 / 03 / 2003$ & M & 189 & Jacaraípe & Serra & Skeleton, teeth & L. Barbosa \\
\hline SOT.23 & $06 / 10 / 2003$ & M & 172 & Santa Cruz & Aracruz & Skeleton, teeth & L. Barbosa \\
\hline SOT.30 & $04 / 04 / 2004$ & M & 196 & Siribeira & Guarapari & Skeleton, teeth & L. Barbosa \\
\hline SOT.31 & $04 / 05 / 2004$ & $\mathrm{UN}$ & 183 & Meaípe & Guarapari & Skeleton, teeth & L. Barbosa \\
\hline SOT.37 & $12 / 09 / 2004$ & $\mathrm{UN}$ & 189 & Formosa & Aracruz & Skeleton, teeth & L. Barbosa \\
\hline SOT.42 & 01/09/2004 & $\mathrm{F}$ & 200 & Ponta da Fruta & Vila Velha & Skeleton, teeth & L. Barbosa \\
\hline SOT.44 & $19 / 11 / 2004$ & $\mathrm{UN}$ & 187 & Santa Cruz & Aracruz & Skeleton, teeth & L. Barbosa \\
\hline SOT.45 & $06 / 04 / 2005$ & M & 166 & Regência & Linhares & $\begin{array}{l}\text { Skeleton, teeth, lung, bone } \\
\text { marrow, muscle, liver, brain }\end{array}$ & L. Barbosa \\
\hline SOT.46 & $06 / 04 / 2005$ & M & 173 & Regência & Linhares & $\begin{array}{l}\text { Skeleton, teeth, liver, lung, } \\
\text { muscle }\end{array}$ & L. Barbosa \\
\hline SOT.48 & $27 / 06 / 2005$ & $\mathrm{~F}$ & 162 & Ilha do Boi & Vitória & $\begin{array}{l}\text { Skeleton, teeth, liver, bone } \\
\text { marrow, lung }\end{array}$ & L. Barbosa \\
\hline SOT.52 & $10 / 01 / 2006$ & M & 169 & Regência & Linhares & $\begin{array}{l}\text { Skeleton, teeth, bone marrow, } \\
\text { muscle }\end{array}$ & L. Barbosa \\
\hline SOT.53 & $16 / 01 / 2006$ & M & 169 & Regência & Linhares & $\begin{array}{l}\text { Skeleton, teeth, muscle, liver, } \\
\text { bone marrow }\end{array}$ & L. Barbosa \\
\hline SOT.56 & $01 / 03 / 2006$ & M & 158 & Regência & Linhares & $\begin{array}{l}\text { Skeleton, teeth, muscle, liver, } \\
\text { bone marrow }\end{array}$ & L. Barbosa \\
\hline SOT.57 & $14 / 03 / 2006$ & $\mathrm{~F}$ & 196 & Setiba & Guarapari & Skeleton, teeth, muscle & L. Barbosa \\
\hline SOT.58 & $17 / 03 / 2006$ & M & 190 & Ilha do Frade & Vitória & Skeleton, teeth, muscle, liver & L. Barbosa \\
\hline SOT.62 & $02 / 01 / 2007$ & $\mathrm{~F}$ & 195 & Costa & Vila Velha & $\begin{array}{l}\text { Skeleton, teeth, muscle, lung, } \\
\text { intestine proximal, distal bowel }\end{array}$ & L. Barbosa \\
\hline SOT.64 & $17 / 01 / 2007$ & M & 198 & Mãe-Bá & Anchieta & $\begin{array}{l}\text { Skeleton, teeth, lung, intestine } \\
\text { proximal, distal bowel }\end{array}$ & L. Barbosa \\
\hline SOT.66 & $22 / 01 / 2007$ & M & 185 & Barrinha & Vila Velha & $\begin{array}{l}\text { Skeleton, teeth, muscle, lung, } \\
\text { liver, intestine proximal }\end{array}$ & L. Barbosa \\
\hline SOT.70 & $15 / 03 / 2007$ & $\mathrm{~F}$ & 185.5 & Costa & Vila Velha & $\begin{array}{l}\text { Skeleton, teeth, lung, kidney, } \\
\text { muscle, liver, intestine } \\
\text { proximal, distal bowel }\end{array}$ & M. Araújo \\
\hline SOT.72 & $06 / 04 / 2007$ & M & 190 & $\begin{array}{l}\text { Morada do } \\
\quad \text { Sol }\end{array}$ & Vila Velha & $\begin{array}{l}\text { Skeleton, teeth, brain, bone } \\
\text { marrow, lung, muscle, intestine } \\
\text { proximal, distal bowel }\end{array}$ & L. Serafim \\
\hline SOT.73 & 09/04/2007 & M & 167 & Regência & Linhares & $\begin{array}{l}\text { Skeleton, teeth, lung, brain, } \\
\text { kidney, liver, muscle, intestine } \\
\text { proximal, distal bowel }\end{array}$ & M. Araújo \\
\hline SOT.79 & $11 / 06 / 2007$ & $\mathrm{UN}$ & 189 & Guriri & São Mateus & Skeleton, teeth & I. Bianchi \\
\hline
\end{tabular}


Table 1. Continued...

\begin{tabular}{|c|c|c|c|c|c|c|c|}
\hline Specimen & $\begin{array}{c}\text { Collection } \\
\text { date }\end{array}$ & Sex & $\begin{array}{r}\text { Total } \\
\text { length }\end{array}$ & Locality & City & Tissues samples stored & $\begin{array}{c}\text { Responsible } \\
\text { staff }\end{array}$ \\
\hline SOT.83 & $12 / 01 / 2007$ & $\mathrm{~F}$ & 183 & Regência & Linhares & $\begin{array}{l}\text { Skeleton, teeth, muscle, } \\
\text { kidney, liver, adipose, intestine } \\
\text { proximal, distal bowel }\end{array}$ & I. Bianchi \\
\hline SOT.84 & $12 / 10 / 2007$ & M & 144.5 & Regência & Linhares & $\begin{array}{l}\text { Skeleton, teeth, liver, lung, } \\
\text { adipose, kidney, intestine } \\
\text { proximal, distal bowel }\end{array}$ & I. Bianchi \\
\hline SOT.85 & $18 / 10 / 2007$ & M & 151.5 & Itapuã & Vila Velha & $\begin{array}{l}\text { Skeleton, teeth, lung, kidney, } \\
\text { adipose, liver, intestine } \\
\text { proximal, distal bowel }\end{array}$ & M. Araújo \\
\hline SOT.86 & $27 / 11 / 2007$ & $\mathrm{~F}$ & 192.5 & Santa Cruz & Aracruz & $\begin{array}{l}\text { Skeleton, teeth, lung, kidney, } \\
\text { liver, muscle, adipose, intestine } \\
\text { proximal, distal bowel }\end{array}$ & I. Bianchi \\
\hline SOT.88 & $20 / 01 / 2008$ & $\mathrm{~F}$ & 151.5 & Centro & $\begin{array}{l}\text { Conceição } \\
\text { da Barra }\end{array}$ & $\begin{array}{l}\text { Skeleton, teeth, lung, kidney, } \\
\text { muscle, liver, adipose, intestine } \\
\text { proximal, distal bowel }\end{array}$ & I. Bianchi \\
\hline SOT.92 & $08 / 03 / 2008$ & $\mathrm{~F}$ & 185 & Manguinhos & Serra & $\begin{array}{l}\text { Skeleton, teeth, kidney, muscle, } \\
\text { lung, liver, adipose, intestine } \\
\text { proximal, distal bowel }\end{array}$ & L. Serafim \\
\hline SOT.93 & $10 / 03 / 2008$ & $\mathrm{~F}$ & 183 & Jacaraípe & Serra & Skeleton, teeth & L. Serafim \\
\hline SOT.94 & $28 / 03 / 2008$ & $\mathrm{~F}$ & 169 & Regência & Linhares & $\begin{array}{l}\text { Skeleton, teeth, liver, lung, } \\
\text { kidney, muscle, adipose, } \\
\text { intestine proximal, distal bowel }\end{array}$ & I. Bianchi \\
\hline SOT.96 & $28 / 04 / 2008$ & M & 190 & Peracanga & Guarapari & $\begin{array}{l}\text { Skeleton, teeth, lung, bone } \\
\text { marrow, liver, muscle }\end{array}$ & I. Bianchi \\
\hline SOT.99 & $21 / 08 / 2008$ & $\mathrm{~F}$ & 119 & Regência & Linhares & $\begin{array}{l}\text { Skeleton, teeth, muscle, } \\
\text { kidney, adipose, liver, intestine } \\
\text { proximal, distal bowel }\end{array}$ & L. Barbosa \\
\hline SOT.103 & $08 / 12 / 2008$ & M & 187 & Solemar & Serra & Skeleton, teeth & L. Serafim \\
\hline SOT.110 & $20 / 03 / 2009$ & UN & 149 & Setiba & Guarapari & $\begin{array}{l}\text { Skeleton, teeth, adipose, liver, } \\
\text { lung, muscle }\end{array}$ & L. Serafim \\
\hline SOT.113 & $29 / 03 / 2009$ & M & 165 & Regência & Linhares & $\begin{array}{l}\text { Skeleton, teeth, muscle, lung, } \\
\text { kidney, liver, adipose, intestine } \\
\text { proximal, distal bowel }\end{array}$ & I. Bianchi \\
\hline SOT.115 & 03/05/2009 & M & 164 & Areia Preta & Guarapari & $\begin{array}{l}\text { Skeleton, teeth, muscle, liver, } \\
\text { intestine proximal, distal bowel }\end{array}$ & L. Serafim \\
\hline SOT.118 & $27 / 07 / 2009$ & M & 165 & Guaibura & Guarapari & $\begin{array}{l}\text { Skeleton, teeth, liver, adipose, } \\
\text { muscle, kidney, intestine } \\
\text { proximal, distal bowel }\end{array}$ & L. Serafim \\
\hline SOT 119 & 06/08/2009 & M & 180 & Castelhanos & Anchieta & $\begin{array}{l}\text { Skeleton, teeth, muscle, lung, } \\
\text { kidney, liver, testicle, intestine } \\
\text { proximal, distal bowel }\end{array}$ & L. Serafim \\
\hline SOT.120 & $15 / 08 / 2009$ & M & 129 & Siribeira & Guarapari & $\begin{array}{l}\text { Skeleton, teeth, muscle, liver, } \\
\text { adipose, lung, kidney, intestine } \\
\text { proximal, distal bowel }\end{array}$ & I. Bianchi \\
\hline SOT 123 & 06/12/2009 & M & 140 & Castelhanos & Anchieta & $\begin{array}{l}\text { Skeleton, teeth, muscle, } \\
\text { kidney, lung, adipose, intestine } \\
\text { proximal, distal bowel }\end{array}$ & L. Barbosa \\
\hline SOT.125 & $21 / 12 / 2009$ & M & 161.3 & Regência & Linhares & $\begin{array}{l}\text { Skeleton, teeth, muscle, } \\
\text { kidney, lung, adipose, intestine } \\
\text { proximal, distal bowel }\end{array}$ & L. Serafim \\
\hline SOT.131 & $17 / 04 / 2010$ & M & 122 & Mãe-Bá & Anchieta & $\begin{array}{l}\text { Skeleton, teeth, liver, kidney, } \\
\text { adipose, muscle, lung, intestine } \\
\text { proximal, distal bowel }\end{array}$ & L. Serafim \\
\hline SOT.133 & $07 / 06 / 2010$ & $\mathrm{M}$ & 174 & Itaipava & Itapemirim & Skeleton, teeth & L. Serafim \\
\hline
\end{tabular}


in a quick-action commercial decalcification agent containing $\mathrm{HCl}\left(\mathrm{RDO}^{\mathrm{TM}}\right)$ for periods between $3 \mathrm{~h}$ and $24 \mathrm{~h}$, depending on the size of sections and on the degree pulpar cavities were filled. The ideal degree of decalcification was established when sections were completely flexible. Decalcified specimens were sectioned again parallel to the longest axis in a microtome-cryostat. Central sections were chosen so as to afford more accurate age readings. Sections were stained using Mayer's hematoxylin to reveal growth layers groups (GLGs). Readings were made in an optical microscope under 40x magnification.

Descriptive statistics was used for mean, maximum, minimum, and standard deviation of total length values. Animals were sorted by dental age as immature ( $\leq 6$ years) and mature ( $\geq 7$ years), and by sex. Inferential statistics included the calculation of growth parameters for TL and predicting the asymptote based on the Gompertz non-linear model, $\mathrm{Y}=\mathrm{ae}[-\mathrm{e}(\mathrm{b}-\mathrm{cx})$ ], where $\mathrm{Y}$ is the measured variable, $\mathrm{a}$ is the asymptote, $\mathrm{b}$ is the correction factor, $\mathrm{c}$ is the growth rate constant, and $\mathrm{x}$ is the age (Zullinger et al., 1984). The model was adjusted using the Curve Expert 1.4 software for Windows.

\section{Results}

The age of 44 S. guianensis specimens was estimated (see Figure 1). Values were between 0.5 year and 33 years $($ mean $=8.34, \mathrm{SD}=7.06)$. Most specimens $(47 \%)$ were between zero and 6 years.

Age of immature males ranged from 1 year to 6 years (mean $=3.08, \mathrm{SD}=1.97)$, while mature males were between 8 and 23 years old ( mean $=12.45, \mathrm{SD}=4.92)$. Immature females varied between 0.5 year and 4 years of age $($ mean $=2.5, \mathrm{SD}=1.32)$, and age of mature females ranged from 7 to 33 years $($ mean $=15.75, \mathrm{SD}=8.20)$ (as shown in Table 2).

The age-based TL growth curve constructed using the Gompertz model indicated that asymptotic lengths was reached at $182 \mathrm{~cm}$, roughly in the 5-6 years age range (correction factor $=-0.54$, growth rate $=0.79$, coefficient of determination, $\mathrm{R}^{2}=0.82$ ) (see Figure 2).

The growth curve for TL (cm) and age (years) adjusted with the Gompertz model for male $S$. guianensis specimens indicated that asymptotic length was reached at approximately $176 \mathrm{~cm}$ (correction factor $=1.28$, growth rate $=2.68$, coefficient of determination, $\mathrm{R}^{2}=0.71$ ) (see Figure 3 ). For $S$. guianensis females, asymptotic length was reached at $191 \mathrm{~cm}$ (correction factor $=-0.44$, growth rate $=-0.54$, coefficient of determination, $\mathrm{R}^{2}=0.96$ ) (Figure 4).
Mean TL for immature males ( $\leq 6$ years) was $166.11 \mathrm{~cm}$ $(\mathrm{SD}=20.34)$. For mature males $(\geq 7$ years $)$, mean TL was $190.18 \mathrm{~cm}(\mathrm{SD}=158.75)$. For immature and mature females mean TL was $158.75 \mathrm{~cm}(\mathrm{SD}=28.19)$ and $191.0 \mathrm{~cm}$ $(\mathrm{SD}=7.12)($ as shown in Table 3$)$.

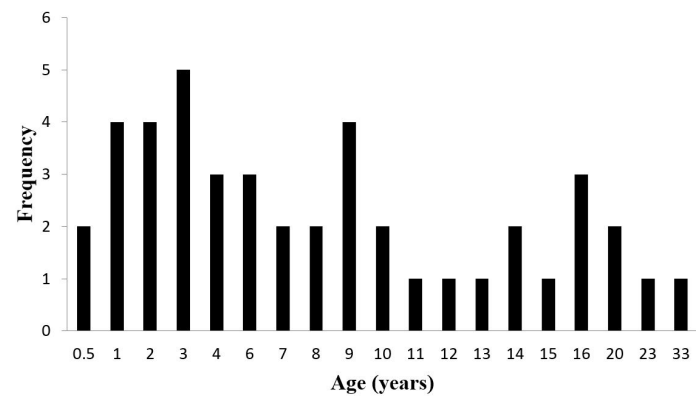

Figure 1. Age (years) frequency of Sotalia guianensis in the state of Espírito Santo, Brazil.

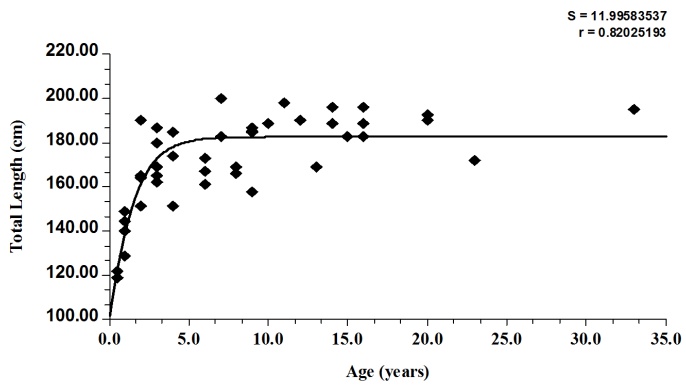

Figure 2. Growth curve adjusted with the Gompertz model for total length $(\mathrm{cm})$ and age (years) for Sotalia guianensis specimens in the state of Espírito Santo, Brazil.

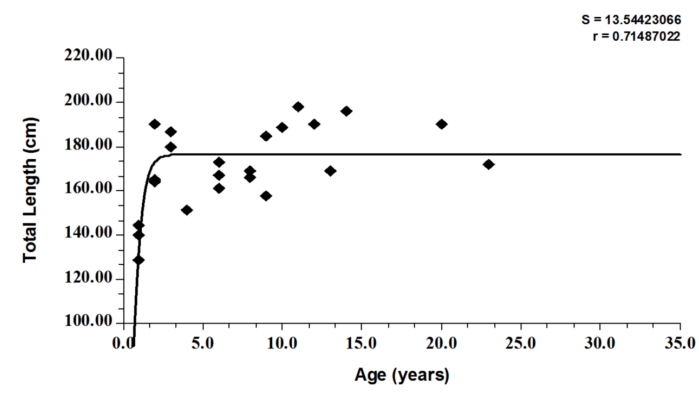

Figure 3. Growth curve adjusted with the Gompertz model for total length $(\mathrm{cm})$ and age (years) for male Sotalia guianensis specimens in the state of Espírito Santo, Brazil.

Table 2. Maximum, minimum, mean, and standard deviation of age (years) of mature and immature male and female Sotalia guianensis specimens in the state of Espírito Santo, Brazil.

\begin{tabular}{|c|c|c|c|c|}
\hline & \multicolumn{2}{|c|}{ Males } & \multicolumn{2}{|c|}{ Female } \\
\hline & Immature & Mature & Immature & Mature \\
\hline Minimum & 1 & 8 & 0.5 & 7 \\
\hline Mean & 3.08 & 12.45 & 2.5 & 15.75 \\
\hline Maximum & 6 & 23 & 4 & 33 \\
\hline Standard deviation & 1.97 & 4.92 & 1.32 & 8.20 \\
\hline
\end{tabular}


Table 3. Maximum, minimum, mean, and standard deviation of total length $(\mathrm{cm})$ of mature and immature male and female Sotalia guianensis specimens in the state of Espírito Santo, Brazil.

\begin{tabular}{lccccc}
\hline & \multicolumn{3}{c}{ Males } & & \multicolumn{2}{c}{ Females } \\
\cline { 2 - 3 } \cline { 5 - 6 } & Immature & Mature & & Immature & Mature \\
\hline Minimum & 129 & 158 & & 119 & 183 \\
Mean & 166.11 & 180.18 & & 158.75 & 191 \\
Maximum & 190 & 198 & & 185 & 200 \\
Standard deviation & 20.34 & 13.68 & & 28.19 & 7.12 \\
\hline
\end{tabular}

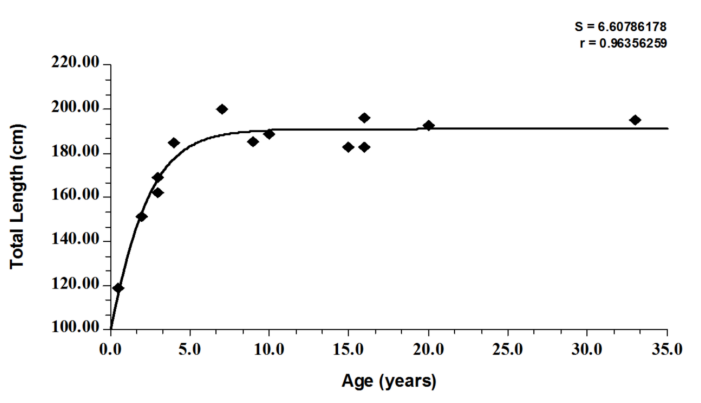

Figure 4. Growth curve adjusted with the Gompertz model for total length $(\mathrm{cm})$ and age (years) for female Sotalia guianensis specimens in the state of Espírito Santo, Brazil.

\section{Discussion}

Previous studies reported lower age variation ranges for S. guianensis in Espírito Santo, Brazil, compared with the values obtained in the present research $($ mean age $=8.34$ years, $\mathrm{SD}=7.06$, minimum $=0.5$ year, maximum $=33$ years $)$. Ramos et al. (2000) analysed S. guianensis found in the north of the state of Rio de Janeiro, Brazil, and suggested that adults may reach the age of 30 years. For Rosas et al. (2003) S. guianensis may live for up to 35 years, though the oldest male observed in their study on the coast of the state of Paraná, Brazil, was 29 years old.

In the present study, age of males varied between 1 and 23 years, while for females the age range was 0.5 year (newly born) to 33 years. Di Beneditto and Ramos (2004) observed that age range was zero -21 years for males and $0.5-33$ years for females in northern Rio de Janeiro state, Brazil. Lailson-Brito et al. (2010) reported that maximum age for $S$. guianensis was 14 years for one male in Guanabara Bay, 13 years for one male in Sepetiba Bay, and 20 years for one female in Paranaguá Bay, all of which are in Brazil. These values are similar, and suggest higher life expectancy for females of the species.

Rosas et al. (2003) believe that young S. guianensis individuals as well as those in the process of reaching sexual maturity (between 4 and 6 years of age) are more susceptible to be captured. Similarly, Di Beneditto and Ramos (2004) reported that males of up to 6 years of age account for $80 \%$ of S. guianensis captured, and suggest that individuals at the beginning of the sexual maturation stage are more vulnerable. For the authors, such vulnerability may be associated with behaviour pattern and composition of populations. In the present study, the age group to which the highest number of animals (47\%) belonged was zero -6 years, which confirms that younger animals at the sexual development stage are more vulnerable to being accidentally captured by fish nets. Significant social organization issues may lead to differential vulnerability based on age groups and sex (IWC, 1994). The excessive decline in populations could indicate a change in the ecosystem (Taylor, 1997). The fact that most animals accidentally captured were at reproductive stage may play a role in population decline, though no in-depth study has evaluated the risks $S$. guianensis is exposed to. Due to the threats faced by the specimens, it has been has suggested that the species should be considered vulnerable, in light of the threats it has had to face (Rosas, 2006).

Using the Von Bertalanfy method, Schmiegelow (1990) estimated that TL asymptote of S. guianensis was $182.6 \mathrm{~cm}$ in the Brazilian states of São Paulo and Paraná. Santos et al. (2003) used the same method to analyse S. guianensis specimens from the same states and reported maximum TL of $186.4 \mathrm{~cm}$. Rosas et al. (2003) analysed S. guianensis from the state of Paraná using the Von Bertalanfy method and observed that males and females reached $186.4 \mathrm{~cm}$ and $177.3 \mathrm{~cm}$ in TL, respectively. However, the authors noticed that growth of males may be discontinuous at the age of 5 years, with a secondary growth process at puberty, which required that separate growth curves for sexes. The Gompertz model is often employed in small cetacean morphology studies (Fernandez and Hohn, 1998; Ramos et al., 2000, 2010; Di Beneditto and Ramos, 2004). Di Beneditto and Ramos (2004) used the Gompertz model to conclude that maximum TL was $191 \mathrm{~cm}$ for $S$. guianensis in northern Rio de Janeiro, a value that is higher than that observed in the other study sites mentioned. Such difference in asymptotic TL may be the result of regional variation between populations. However, in the present study the asymptotic TL value was near the mean value, when compared with the other regions surveyed. TL of 44 S. guianensis individuals varied between $119 \mathrm{~cm}$ ad $200 \mathrm{~cm}$, with mean of $174.10 \mathrm{~cm}$ and SD of $20.51 \mathrm{~cm}$.

Ramos et al. (2010) reported that TL of S. guianensis from the state of Espírito Santo varied between 175.0 and $222.0 \mathrm{~cm}$ for males and 166.0 and $184.5 \mathrm{~cm}$ for females. For mature individuals TL varied between 167.0 and $222.0 \mathrm{~cm}$, similarly to the values observed in the present study. In the north of the state of Rio de Janeiro, TL of males varied between 86.0 and $200.0 \mathrm{~cm}$, while TL of females ranged from 117.5 and $198.0 \mathrm{~cm}$. TL of mature individuals varied 
between 161.0 and $200 \mathrm{~cm}$. The specimens evaluated in the state of São Paulo presented mean TL values that were shorter than those of $S$. guianensis from Rio de Janeiro and Espírito Santo (Ramos et al., 2010). As observed by Ramos et al. (2010), length obeys a clinal gradient that increases with latitude and, under specific conditions, factors other than heat conservation may affect geographic variation, such as nutrition requirements.

Variations in TL of $S$. guianensis were observed across its distribution range. The largest individual observed was a female found stranded on the coast of Espírito Santo measuring $206.0 \mathrm{~cm}$ (Barros, 1991). Di Beneditto and Ramos (2004) recorded maximum TL of $200 \mathrm{~cm}$ for a male and $198 \mathrm{~cm}$ for a female in the north of Rio de Janeiro state. Lailson-Brito et al. (2010) observed that maximum TL of $S$. guianensis in Guanabara Bay was $191 \mathrm{~cm}$, while TL of animals from the Sepetiba and Paranaguá bays were $195 \mathrm{~cm}$ and 198 cm, respectively. However, Barbosa and Barros (2006) estimated TL values and declared that maximum TL for the species would be $222 \mathrm{~cm}$. For the state of Espírito Santo, maximum TL was observed in the present study were $200 \mathrm{~cm}$ for females and $198 \mathrm{~cm}$ for males, though age of individuals was not assessed. TL data obtained here were similar to those cited above.

The $S$. guianensis individuals found on the coast of the state of Espírito Santo, Brazil had higher mean TL than animals surveyed in other locations. Variation in TL between animals of different regions was discussed by Cunha et al. (2010), who described changes in the parameter across animals of various geographic regions using DNA analysis that indicated distinct $S$. guianensis populations in the states of Pará, Ceará, Rio Grande do Norte, Bahia, Espírito Santo, and in the southeast and south states (Rio de Janeiro, São Paulo, Paraná e Santa Catarina). Similarly, Caballero et al. (2006) pointed to the differences between Caribbean and South and Central American specimens. However, the same authors observed small genetic differences between populations living on the Brazilian coast (Caballero et al., 2010).

Most morphometric studies with cetaceans used cranium and skeleton parameters (Perrin et al., 2003). Little research has used external morphological parameters, possibly due to the difficulty to obtain samples. Also, some characters are affected by changes occurred after the animal died, especially due to decomposition (Wang et al., 2000).

Age estimates based on GLGs are a useful tool in the determination of sexual maturity and development stage of individual. In like manner, studies about the degree of morphological, genetic, or behavioral changes in cetaceans afford to better understand the evolutive processes underwent by one species, and are useful in the management of populations (Wiig, 1992). Younger animals are more susceptible to being captured accidentally, especially males, which highlights the importance of studies and of monitoring programs in conservation efforts for this species.

\section{Acknowledgements}

The authors are grateful to Coordenação de Aperfeiçoamento de Pessoal de Nível Superior (CAPES) and ORCA institute for allowing using the samples that enabled the conduction of this study.

\section{References}

AMANO, M. and MIYAZAKI, N., 1992. Geographic variation and sexual dimorphism in the skull of Dall's porpoise, Phocoenoides dalli. Marine Mammal Science, vol. 8, no. 3, pp. 240-261. http:// dx.doi.org/10.1111/j.1748-7692.1992.tb00407.x.

AZEVEDO, C.T., LIMA, J.Y., AZEVEDO, R.M., SANTOS NETO, E.B., TAMY, W.P., BARBOSA, L.A., BRITO, J.L., BOERE, V. and DA SILVEIRA, L.S., 2015. Thoracic limb bone development in Sotalia guianensis (Van Bénéden 1864) along the coastline of Espírito Santo, Brazil. Journal of Mammalogy, vol. 96, no. 3, pp. 1-11. http://dx.doi.org/10.1093/jmammal/gyv059.

BARBOSA, L.A. and BARROS, N.B., 2006. Aspectos da distribuição, biologia e captura acidental de boto cinza (Sotalia guianensis) no litoral do Espírito Santo, Brasil. In: Workshop on Research and Conservation of the Genus Sotalia: Book of Abstracts, 2006, Rio de Janeiro. Rio de Janeiro: Escola Nacional de Saúde Pública, FIOCRUZ. 62 p.

BARROS, N.B., 1991. Recent cetacean records for Southeastern Brazil. Marine Mammal Science, vol. 7, no. 3, pp. 296-306. http:// dx.doi.org/10.1111/j.1748-7692.1991.tb00104.x.

BUTTI, C., CORAIN, L., COZZI, B., PODESTÀ, M., PIRONE, A., AFFRONTE, M. and ZOTTI, A., 2007. Age estimation in the Mediterranean bottlenose dolphin Tursiops truncatus (Montagu 1821) by bone density of the thoracic limb. Journal of Anatomy, vol. 211, no. 5, pp. 639-646. http://dx.doi.org/10.1111/j.14697580.2007.00805.x. PMid:17850286.

CABALLERO, S., TRUJILLO, F., VIANNA, J.A., BARRIOSGARRIDO, H., MONTIEL, M.G., BELTRÁN-PEDREROS, S., MARMONTEL, M., SANTOS, M.C.O., ROSSI-SANTOS, M.R., SANTOS, F.R. and BAKER, C.S., 2010. Mitochondrial DNA diversity, differentiation and phylogeography of the South American riverine and coastal dolphins Sotalia fluviatilis and Sotalia guianensis. The Latin American Journal of Aquatic Mammals, vol. 8, no. 1-2, pp. 69-79. http://dx.doi.org/10.5597/lajam00155.

CABALLERO, S., TRUJILLO, F., VIANNA, J.A., BARRIOSGARRIDO, H., TRUJILLO, F., VIANNA, J.A., BARRIOSGARRIDO, H., MONTIEL, M.G., BELTRÁN-PEDREROS, S., MARMONTEL, M., SANTOS, M.C.O., ROSSI-SANTOS, M., SANTOS, F.R. and BAKER, C.S., 2006. Phylogeography of the South American riverine and coastal dolphins Sotalia fluviatilis and Sotalia guianensis. In: Workshop Internacional sobre Pesquisa e Conservação dos Golfinhos do Gênero Sotalia, 2006, Búzios. Búzios: Sociedad Latino Americana de Especialistas en Mamíferos Acuáticos.

CARVALHO, A.P.M., YWASAKI, J., AZEVEDO, C.T., BOTTA, S., QUEIROZ, F.F., CAMPOS, A.S., BARBOSA, L.A. and SILVEIRA, L.S., 2015. Ossifications Pattern of estuarine dolphin (Sotalia guianensis) forelimbs, from the coast of the state of Espírito Santo. PLoS One, vol. 10, no. 5, pp. 1-10. http://dx.doi. org/10.1371/journal.pone.0127435. PMid:26017269.

CUNHA, H.A., SILVA, V.M.F. and SOLÉ-CAVA, A.M., 2010. Molecular Ecology and Systematics of Sotalia Dolphins. In: 
M. RUIZ-GARCIA and J. SHOSTELL. Biology, evolution and conservation of River Dolphins. New York: Nova Science Publishers, pp. 261-283.

DI BENEDITTO, A.P. and RAMOS, R.M.A., 2004. Biology of the marine tucuxi dolphin (Sotalia fluviatilis) in south-eastern Brazil. Journal of the Marine Biological Association of the United Kingdom, vol. 84, no. 6, pp. 1245-1250. http://dx.doi.org/10.1017/ S0025315404010744h.

EDWARDS, H.H. and SCHNELL, G.D., 2001. Status and ecology of Sotalia fluviatilis in the Cayos Miskito Reserve, Nicaragua. Marine Mammal Science, vol. 17, no. 3, pp. 445-472. http:// dx.doi.org/10.1111/j.1748-7692.2001.tb00998.x.

FERNANDEZ, S. and HOHN, A.A., 1998. Age, growth, and calving season of bottlenose dolphins, Tursiops truncatus, off coastal Texas. Fish Bulletin, vol. 96, no. 2, pp. 357-365.

HOHN, A.A., SCOTT, M.D., WELLS, R.S., SWEENEY, J.C. and IRVINE, A.B., 1989. Growth layers in teeth from known age, free-ranging bottlenose dolphins. Marine Mammal Science, vol. 5, no. 4, pp. 315-342. http://dx.doi.org/10.1111/j.1748-7692.1989. tb00346.x.

INSTITUTO BRASILEIRO DO MEIO AMBIENTE E DOS RECURSOS NATURAIS RENOVÁVEIS - IBAMA, 2001. Mamíferos aquáticos do Brasil: plano de ação. Brasília: Edições IBAMA. 102 p. vol. 2.

INTERNATIONAL UNION FOR CONSERVATION OF NATURE - IUCN. IUCN World Conservation Union, 2003 [viewed 30 January 2014]. 2003 IUCN Red list of Threatened Animal [online]. Cambridge: IUCN. Available from: http://www.redlist.org

INTERNATIONAL WHALING COMMISSION - IWC, 1994. Report of the workshop on mortality of cetaceans in passive fishing nets and traps. Report of the International Whaling Commission. Special Issue, no. 15, pp. 1-71.

LAILSON-BRITO, J., DORNELES, P.R., AZEVEDO-SILVA, C., AZEVEDO, A.F., VIDAL, L.G., ZANELATTO, R.C., LOZINSKI, C.P., AZEREDO, A., FRAGOSO, A.B., CUNHA, H.A., TORRES, J.P. and MALM, O., 2010. High organochlorine accumulation in blubber of Guiana dolphin, Sotalia guianensis, from Brazilian coast and its use to establish geographical differences among populations. Environmental Pollution, vol. 158, no. 5, pp. 1800-1808. http://dx.doi.org/10.1016/j.envpol.2009.11.002. PMid:19932538.

PERRIN, W.F., DOLAR, M.L.L., AMANO, M. and HAYANO, A., 2003. Cranial sexual dimorphism and geographic variation in Fraser's dolphin, Lagenodelphis hosei. Marine Mammal Science, vol. 19, no. 3, pp. 484-501. http://dx.doi.org/10.1111/j.1748-7692.2003. tb01316.x.

PINEDO, M.C. and HOHN, A.A., 2000. Growth layer patterns in teeth from the fransciscana, Pontoporia blainvillei: developing a model for precision in age estimation. Marine Mammal Science, vol. 16, no. 1, pp. 1-27. http://dx.doi.org/10.1111/j.1748-7692.2000. tb00901.x.

RAMOS, R.M.A., DI BENEDITO, A.P.M. and LIMA, N.R.W., 2000. Growth parameters of Pontoporia blainvillei and Sotalia fluviatilis (Cetacea) in northern Rio de Janeiro, Brazil. Aquatic Mammals, vol. 26, no. 1, pp. 65-75.
RAMOS, R.M.A., DI BENEDITTO, A.P.M., SICILIANO, S., SANTOS, M.C.O., ZERBINI, A.N., VICENTE, A.F.C., ZAMPIROLLI, E., ALVARENGA, F.S., FRAGOSO, A.B., LAILSON-BRITO, J., AZEVEDO, A.F., BARBOSA, L. and LIMA, N.R.W., 2010. Morphology of the Guiana Dolphin (Sotalia guianensis) off Southeastern Brazil: growth and geographic variation. The Latin American Journal of Aquatic Mammals, vol. 8, no. 1-2, pp. 137-149. http://dx.doi.org/10.5597/lajam00163.

ROSAS, F.C.W., 2006. Natural history of dolphins of the genus Sotalia. İn: Workshop on Research and Conservation of the genus Sotalia, 2006, Búzios. Rio de Janeiro, p. 30.

ROSAS, F.C.W., BARRETO, A.S. and MONTEIRO-FILHO, E.L.A., 2003. Age and growth of the estuarine dolphin (Sotalia guianensis) (Cetacea, Delphinidae) on the Paraná coast, southern Brazil. Fish Bulletin, vol. 101, no. 2, pp. 377-383.

SANTOS, M.C.O., ROSSO, S. and RAMOS, R.M.A., 2003. Age estimation of marine tucuxi dolphins (Sotalia fluviatilis) in SouthEastern Brazil. Journal of the Marine Biological Association of the United Kingdom, vol. 83, no. 1, pp. 233-236. http://dx.doi. org/10.1017/S0025315403007021h.

SCHMIEGELOW, J.M.M., 1990. Estudo sobre cetáceos odontocetos encontrados em praias da região entre Iguape (SP) e Baía de Paranaguá (PR) $\left(24^{\circ} 42^{\prime} S-25^{\circ} 28^{\prime}\right.$ S) com especial referência a Sotalia fluviatilis (Gervais, 1853) (Delphinidae). São Paulo: Programa de Pós-graduação em Oceanografia, Universidade de São Paulo, 149 p. Masters Degree Dissertation in Biological Oceanography.

SIMÕES-LOPES, P.C., 1988. Ocorrência de uma população de Sotalia fluviatilis (Grevais, 1853), (Cetacea, Delphinidae) no limite sul de sua distribuição, Santa Catarina, Brasil. Biotemas, vol. 1 , no. 1 , pp. 57-62.

TAYLOR, B.L., 1997. Defining 'population' to meet management objectives for marine mammals. In: A.E. DIZON, S.J. CHIVERS and W.F. PERRIN. Molecular genetics of marine mammals. Lawrence: Society for Marine Mammalogy, pp. 49-65. Special Publication, no. 3 .

WANG, J.Y., CHOU, L.S. and WHITE, B.N., 1999. Mitochondrial DNA analysis of sympatric morphotypes of bottlenose dolphins (genus:Tursiops) in Chinese waters. Molecular Ecology, vol. 8, no. 10, pp. 1603-1612. http://dx.doi.org/10.1046/j.1365294x.1999.00741.x. PMid:10583824.

WANG, J.Y., CHOU, L.S. and WHITE, B.N., 2000. Osteological differences between two sympatric forms of bottlenose dolphins (genus Tursiops) in Chinese waters. Journal of Zoology, vol. 252, no. 2, pp. 147-162. http://dx.doi.org/10.1111/j.1469-7998.2000. tb00611.x.

WIIG, O., 1992. Carnivore morphometrics: a study of skull variation and its significance. Bergen: Zoological Museum, University of Bergen. PhD Thesis.

ZULLINGER, E.M., RICKLEFS, R.E., REDFORD, K.H. and MACE, G.M., 1984. Fitting sigmoidal equations to mammalian growth curves. Journal of Mammalogy, vol. 65, no. 4, pp. 607636. http://dx.doi.org/10.2307/1380844. 